\title{
Security Cooperation during the Novel Coronavirus Pandemic
}

Dmitry A. Medvedev

\section{Dmitry A. Medvedev}

Deputy Chairman of the Security Council of the Russian Federation

Address: Government House, 2 Krasnopresnenskaya Naberezhnaya, Moscow 103274, Russia

DOI: $10.31278 / 1810-6374-2020-18-3-10-22$

\begin{abstract}
The coronavirus pandemic compels us to reassess the main risks the world and individual countries, including Russia, are facing, and reconsider basic principles of international cooperation in global security. Urgent concerted efforts should focus on three major tasks: ensuring global and people's individual security; enhancing law enforcement, including anti-terrorist programs with a special emphasis placed on cybersecurity and fight against bio-hazards; and promoting robust functioning of the global economy and national economies. The pandemic has set new requirements for sectors directly influencing people's living conditions: education, healthcare, labor, recreation, the motivation system, etc. The response to the new challenges posed by the pandemic crisis must be universal, which implies consistent full-fledged interaction between governments, institutions, and businesses. It is important to strike a balance between the interests of the state and individuals, maintain due transparency, and share information, skills and various technological solutions.
\end{abstract}

Keywords: pandemic, world order, Russia, global security, international cooperation, international institutions, governance. 
"This is the form of the formless, being in non-being. It is nebulous and elusive. Meet it, and you do not see its beginning. Follow it, and you do not see its end."

Lao Tzu, Tao Te Ching

\begin{abstract}
few months back, when the first news about an unknown coronavirus disease began to come from the Chinese city of Wuhan, no one could imagine that the disease behind the COVID-19 acronym would have such an effect on humankind.
\end{abstract}

Millions of people got sick and hundreds of thousands died. Healthcare systems are operating at their limits. Doctors are working without rest or sleep. And all of that amid the apocalyptic images of deserted cities, frozen airports, closed businesses and organizations, sealed borders and, as a result, national economies in freefall. The crisis did more than endanger the lives of millions of people. It exposed risks that the most advanced and technically developed nations were not prepared for. It dealt a severe blow to globalization, which was considered the mainstay of international cooperation in the 21 st century.

Today, researchers, analysts, managers, and politicians across the globe focus on finding out what we are dealing with. Is the virus manmade or natural, meaning it has primary biological carriers? Who is to blame for the rapid spread of the pandemic? Most importantly, what is to be done? How should we respond to this global challenge? We need vaccines and medicine to combat the virus. Potent drugs are needed both by the global economy and the economies of individual countries. Large numbers of people need help and support. There will be a need for vast amounts of money to revive the economy. Equally important is the question of how long this pandemic will last. Will the second wave hit the world and, if so, when? Will people around the world develop herd immunity in the near future? And the list goes on. Truly, the crisis has taken on an existential dimension for everyone.

There are no easy answers to these questions. Some of them, I am almost sure, will remain unanswered. However, what is probably most important now is not the answers themselves, but a coordinated all- 
out effort to overcome the largest ever-and truly global—crisis that is unprecedented in recent history. The risks it has created are extremely high. That is why we need global security cooperation in the broadest sense of the word.

Outstanding Russian scientist Konstantin Tsiolkovsky said: "The people who will learn to unite will enter the Golden Age..." Humanity has confirmed the truth of this saying on many occasions. In the Middle Ages, plague epidemics had a huge impact on the development of medicine and public administration. Cholera was an equally powerful catalyst in the 19th century, as was the Spanish flu in the early 20th century. Healthcare conferences became possible only thanks to international cooperation and brought together doctors, epidemiologists and demographers who worked out effective responses to diseases. Their joint work made it possible to establish the World Health Organization (WHO) in 1948, and to create a line of medicines that we know as antibiotics.

However, back then, the organization and institutionalization of such interaction took years and even decades. There were no means of rapid dissemination of information, and the world was very far from the modern level of communication in general. Today, it has become much more interconnected, and digital technologies offer humanity almost limitless opportunities for interaction without wasting time, which, as we have seen once again, is too precious.

What are the main risks facing the world and individual countries, including Russia? What kind of global security collaboration do we need?

First comes cooperation to ensure global and everyday individual security, that is, security for all of us and each and every one of us individually. It may sound trite, but the pandemic knows no borders. Therefore, it is impossible to defeat it in one country, even with closed borders, severed transport links and other means of communication between people. In the Middle Ages, a town (which was essentially a fortress) hit by the plague was locked down completely, and most of its inhabitants were doomed.

It should be a reasonably open collaboration. Everyone is talking about it now. The question is how open it should be. Each country 
and each company understands it in its own way. Of course, for reasons of national or corporate security, much will remain off-limits anyway. However, in certain situations, countries will have to agree to direct cooperation, which I would call "forced cooperation." Take for instance, mandatory interaction during the COVID-19 vaccination campaign. When good vaccines become available, they should be used almost simultaneously on all continents, primarily for reasons of national security. It is unlikely that anyone would want to have a neighbor capable of throwing a coronavirus bomb into his backyard at any moment. The same applies to research underway in certain labs, including the ones that the United States has deployed all over the planet. Their activities should not cause any suspicion, otherwise with a new outbreak of any infectious disease (no one doubts that more such outbreaks are coming) there will be endless mutual complaints, conspiracy theories and cross-sanctions which will pave the way for a direct conflict. Everyone will then suspect each other of everything, and each new virus will be presented as a biological weapon. These risks will entail unheard-of international tensions, which can easily escalate into a full-fledged conflict, rather than the so-called "hybrid" war.

Reasonable transparency and agreed-upon verification are needed here. Russia remains committed to such an important international document as the Biological Weapons Convention. At this point, this one-of-a-kind agreement needs to be thoroughly reviewed to fully reflect modern realities. Unfortunately, not all our partners agree with this. For example, the United States ratified the Convention in 1972, but verifying its implementation by Washington using international legal means is not possible now. In 2001, our U.S. colleagues refused to adopt the relevant protocol to the Convention and stopped to allow onsite inspections. Today, Russia is calling for full compliance with the Convention, thus reminding the international community that using biological weapons is unacceptable. I hope Washington will hear what our country has to say about it and will start a more open and engaged dialogue with the states parties to the Convention. Undoubtedly, the principles of international cooperation in biological research will need to be revised after the pandemic. This work can be done at the 
$\mathrm{UN}$, including its WHO institution, and regional venues, such as the CSTO or the SCO, which pay significant attention to various aspects of security.

The off-limits research will not go anywhere and will continue to ensure national security and corporate interests. However, we need protocols agreed upon by the countries as to the procedure to be used in the event of a pandemic threat, and what the international community partners and the WHO should be notified about. In that case, there will be no endless squabbling over who was zero patient, who hid what, and what was done and what was not.

Clearly, current investigations into the causes of the pandemic are part of the domestic policies of individual countries, which underlies election campaigns. This creates the states that are "under investigation," which are blamed for economic failures and the fight against coronavirus. Claims worth trillions of dollars are being filed. It is a dead-end policy that will not do anyone any good, even during elections. It is much more productive to provide a full-fledged platform for cooperation between doctors, researchers, laboratories, and companies in order to obtain a collective result. Indeed, developing a truly effective vaccine and a group of antiviral drugs will take a long time and the contribution of each country, its researchers and companies can be truly unique.

Let me stress this again. When this work begins, all countries should establish open and vigorous interaction among their governments, scientists and businesses on the basis of modern international law. In the meantime, political cooperation is lagging far behind the expert dialogue, in which over 70 countries are already participating. Politicians can be credited only for the prompt provision of relief to the countries most affected by the pandemic, which, of course, is a great deal. But I am sure that smoothing out political differences that impede a full-fledged international dialogue, at least during the fight against the pandemic, would stimulate cooperation between states and save a lot of time and effort. It is no coincidence that Russia almost immediately after the outbreak of the pandemic came up with an initiative to lift sanctions in order to facilitate access to the necessary aid for the worst 
affected countries. We were instantly accused of pursuing our own interests, although the resolution was not about Russia, but the states in an extremely difficult situation, such as Venezuela and Iran. The United States, the EU, Great Britain, Ukraine, and Georgia immediately blocked Russia's draft resolution at the UN General Assembly. Given the pandemic, this decision cannot be described in any way other than immoral and irresponsible.

Second, coordinating the international community's efforts in the law enforcement sphere. Crises tend to provoke destructive forces, and the risks of extremists taking advantage of civilizational vulnerabilities and the threat of terrorist attacks increase many times over. For obvious reasons, COVID-19 is forcing the security services to step up their work, primarily in order to maintain stability in their respective countries. No matter how difficult the situation may be now, the global counterterrorism interaction between security services must remain strong. The coronavirus pandemic has clearly shown humanity's vulnerability to instantaneous infection of millions of people. This, in turn, can be a motive for using extremely dangerous bioterrorism technologies. That is why the state must exercise strict control over biotechnologies and bio-laboratories, and the security services should join efforts in order to prevent terrorist attacks with the use of biological agents.

The pandemic has also led to a surge in cybercrime. Today, with the ever increasing use of digital solutions in everyday life and companies switching to telecommuting and opening access to their in-house data, cyber criminals, hackers and peddlers of counterfeit products find it easier to target their victims. The Internet is becoming more open, which is fraught with enormous risks, and makes the World Wide Web an ideal place for criminal gangs. Until recently, it was hard to imagine that major companies will switch to online meetings and use Zoom and the like for holding them. Any program has its own features that make it possible to use it for purposes that lie far from high moral principles.

E-commerce has become widely popular during the pandemic, including everyday shopping at online stores and major online 
transactions involving digital payment methods. E-commerce is measured in hundreds of billions of dollars and will expand regardless of what course the pandemic may take. This is an irreversible process. However, cybercrime will also be on the rise and new scams will appear that law enforcement agencies will have to respond to quickly. Moreover, the cross-border nature of such transactions will call for new forms of cooperation between the law enforcement agencies of different countries and the use of the latest technology for detecting and stopping crimes.

Here in Russia, the Security Council, law enforcement and other agencies are working hard to develop a national cybersecurity system. We urge the international community to join efforts in order to ensure global security in the digital world.

Third, ensuring stable and, therefore, relatively safe functioning of the global economy and national economies. The pandemic has created unprecedented challenges for the global economy. All countries have been affected by the pandemic. There are countries that have already defaulted on their obligations, and major transnational companies are going bankrupt. According to the IMF, the global economy is expected to contract by as much as 3 percent in 2020 compared to 2019 due to the crisis. This is the biggest drop in global GDP since World War II. To compare, the largest annual decline was a paltry 0.1 percent during the most recent global financial and economic crisis in 2008-2009.

What really makes this situation different is that economic considerations became secondary to medical considerations. The choice of economic policy essentially became a choice between economic growth and saving lives, which depends on the traditions and the level of trust in each society. However, a drawn-out economic decline is fraught with human casualties as well.

What does this all mean in terms of the challenges facing the economy? At least in the short term, GDP will cease to be a critically important criterion for assessing growth dynamics. Moreover, the problem is not so much in the extent of the recession as its duration. A deep, but short-lived decline will be followed by a rebound with subsequent growth, which may not even require any extra investment. 
However, extended stagnation is far more dangerous as it tends to destroy infrastructure and degrade all aspects of life.

Of course, Russia will not escape a general economic recession. According to the Ministry of Economic Development, the country's GDP will fall by 5 percent in 2020, real incomes are expected to drop by 3.8 percent and unemployment to rise to 5.7 percent, reaching its highest in the past nine years. Today, our country is hit by three economic shocks. First, the falling global oil prices. This is the biggest shock, since the domestic economy remains dependent on hydrocarbon exports. However, over the past 20 years, Russia has withstood such blows three times, in the late 1990s, in 2008-2009, and in 2014-2015, meaning that it is not difficult to assess the impact of this shock on the economy and pinpoint the most effective measures to alleviate its ramifications. The main blow is expected to come in 2020. In 2021, the economy will adapt to the new circumstances, regardless of the oil prices.

However, the second, internal, shock, which was the result of the regulatory decisions by the state trying to slow down the spread of the coronavirus infection, is unprecedented. On the face of it, it is reminiscent of the situation in the early 1990s, when individual economic agents dropped out of the economic process, thus severing existing ties. But this comparison works only partly, to say the least. The current problems in the real sector of the economy, the labor market, the social sphere, and the banking sector are unprecedented in their nature, and standard approaches to analyzing economic and financial crises are not applicable here. The closing of businesses cannot be explained by poor competitiveness of the companies or the goods. After all, their closing was primarily caused by non-economic decisions. Moreover, under quarantine, maximum restrictions apply to the service sector, where production chains are normally straightforward and short (small businesses and service sector). Therefore, the recession may be limited to the period of the regulatory decisions, and economic recovery will begin fairly quickly, unless, of course, new waves of the epidemic lead to another round of forced restrictions.

Finally, there is a third shock associated with the declining international demand for a wide range of domestic goods due to a 
slowdown in the global economy. A similar situation was observed in 2008-2009 during the global financial and economic crisis. The scale of the current decline in Russia's exports can be seen if you compare them with that period. The current decrease in global trade and demand is also largely due to restrictive measures and temporary rupture of economic and logistics ties. Therefore, the duration of this fall may be limited to the duration of strict quarantine measures, after which the demand will recover. Here, too, there is a threat of a new outbreak of the pandemic, which can inflict a debilitating blow to the global economy that can only be compared to a world war.

The speed of demand recovery also depends on the state of the global economy before the shock. In 2007-2008 it was largely overheated after a decade of rapid growth and has been growing quite slowly up until now. Therefore, if the pandemic gradually subsides, the depth of the recession after the first round of restrictions on doing business is unlikely to increase and the ensuing return to the natural level of demand can be quite fast. However, it is unlikely to exceed the pre-crisis demand and trade levels.

The current unfavorable situation may provoke another financial crisis in one or more countries. This, in turn, will put Russia's financial and currency markets under pressure and trigger further decrease in demand for Russian exports. The likelihood of this shock increases over time, and the risk will be higher in 2021 than in 2020. We must be prepared for this as well.

It is important that the government has approved the anti-crisis plan and submitted it to the president. The most important thing now is to implement it and make adjustments, if needed. We must provide extensive support to individuals and companies, which will help to avoid a sharp drop in aggregate supply and demand, and to prevent the growth of poverty rates. Then, the economy should reboot and national projects should be implemented, in an adjusted form, if needed. A new economic growth model replete with structural reforms should be launched during the next stage.

However, the pandemic is making forecasting the economic processes significantly more difficult. Therefore, I will now give only 
a few socioeconomic policy principles for the first stage of opening the economy. First, a gradual lifting of the restrictions, provided the healthcare system is ready and properly equipped to deal with the pandemic. Second, support for people, including employees and sole proprietors. This implies the need to reform labor legislation, including remote employment regulations. Third, the efforts designed to stimulate supply, primarily by reducing the cost of doing business. Small businesses may need additional support as the quarantine is lifted. Fourth, further streamlining of supervision and oversight procedures. Fifth, the maximum possible preservation of budgetary obligations in the current circumstances, including investment.

Of course, the support provided by the state should be commensurate to economic losses and decline in households' incomes. Clearly, the reality will be more complex and adjustments will be needed even during the initial stage of overcoming the crisis.

When dealing with the pandemic and the related economic crisis, it is important not to lose sight of long-term challenges and goals. The uncertainty and unpredictability of the global economy that have been observed in recent years have reached their highest point. We are witnessing the formation of new social and economic institutions and mechanisms based on the latest technological solutions.

A detailed analysis of the solutions related to creating new anticrisis institutions should already be underway. It is imperative to understand which institutions are short-lived and need to be eliminated eventually, and which ones represent a breakthrough into the future.

Digital technologies will undoubtedly become the most important driver behind the socioeconomic and political development in the postpandemic world. It is critically important to draw a line between the benefits provided by digital technology and the threat of a digital Big Brother and restrictions on fundamental human rights and freedoms. The economic efficiency that comes with digital technologies cannot be bought at the cost of digital totalitarianism.

Organizing the manufacturing processes in the new environment is a separate matter. Many business standards will need to be revised with account taken of the epidemiological risks, which will most likely 
increase the economic costs. At the same time, digital technologies have the potential to offset these costs, but this will give rise to the need to develop new structural and institutional solutions. The regulatory guillotine in these circumstances does not recede into the background. On the contrary, its relevance increases sharply, because digital technologies not only make it possible, but, in fact, require that we firmly reject obsolete forms of oversight and supervision that impede socioeconomic growth.

The pandemic has set new requirements for the sectors that directly determine living conditions, such as education and healthcare, labor and recreation, the motivation system and much more. It will be necessary to rethink the long-term role of digital technologies in all these areas and make sure they benefit from it significantly since human capital (or, more precisely, human potential) is a key factor in the 21 st century competition. We must clearly understand that global cooperation, the need for which the pandemic has emphasized once again, does not eliminate global competition.

However, competition does not eliminate the need for international economic cooperation, the importance of which is increasing significantly. Many countries are facing the problem of funding their social obligations and debt payments. The developed economies should be willing to provide support in order to ensure global social, financial and economic stability. The past months have shown that various countries and international organizations are ready to cooperate and interact as they confront challenges. International organizations have come up with significant financial commitments to combat the pandemic. For example, G20 states promised to allocate a total of \$5 trillion to support the member countries' economies.

The introduction of restrictive measures in trade in goods and services by a number of countries has undermined the international trading system and value chains. However, in accordance with the G20 and APEC agreements, the WTO and the WHO recommendations, the restrictive trade measures adopted as pandemic relief should be proportionate and temporary. The pandemic has impacted trade agreements as well. The implementation of the agreement on 
the African Continental Free Trade Area was postponed, and the negotiations on a free trade agreement between the EU and the UK were suspended. The implementation of the first phase of a trade deal between the United States and China is in jeopardy.

Given the circumstances, Russia should adhere to free trade principles while taking into account objective requirements for protecting life and health and ensuring our national interests. It should encourage digital commerce based on information security and protection of personal data. In the EAEU, modern challenges will facilitate cooperation in healthcare and the development of a mechanism for a joint response to epidemiological challenges in a single mobile labor market. The time is right to enhance remote collaboration between medical institutions in Russia and its EAEU partners and to expand the presence of Russian education in the EAEU countries by way of connecting their universities to distance learning programs or individual events held by Russian universities.

Finally, perhaps the most urgent and, therefore, the most important thing. In addition to economic recovery, the greatest difficulties facing the authorities will be related to organizing safe daily routines. Countries that are gradually emerging from quarantines have every reason to worry about how the coronavirus will affect the lives of major cities. The managers of different levels are facing challenges that were unthinkable in the recent past. How, with a highly contagious virus, can people safely and freely move around, go to work and do the shopping? Is there a need to enforce social distancing and wearing of face masks? Let's face it, all of that disrupts our lives. Some countries plan to take tough steps and introduce "health passports" which will make it possible to quickly identify infected visitors who arrive in a particular country, or "immunity passports" for the people who have recovered from COVID-19.

The desire of the governments to approve or preserve certain rules of new social relations is quite understandable: a long face-off with the virus and a slow victory over it come at too high a price. However, it is important to strike a balance between the interests of the state and individuals, their civil rights, and not provoke panic and discontent 
among people (social protests in the United States and a number of other countries prove this very clearly). Relying on other countries' experience makes sense if it has positive effects even in the early stages of implementation.

This coronavirus pandemic is a unique event as it directly affects all aspects of our lives. In this difficult period, transparency is the main prerequisite for survival. It is important to share scientific and practical information, skills and various technological solutions. Countries and people should join efforts and support and help each other as needed. It is in our common interest to set aside unnecessary disputes and differences as soon as possible. In his novel The Plague, Albert Camus said "The tale he had to tell could not be one of a final victory. It could only be the record of what had to be done, and what assuredly would have to be done again in the never-ending fight against terror and its relentless onslaughts."

Therefore, only close cooperation will allow us to defeat the virus, which has not gone anywhere and is still the common enemy of humanity. 